\title{
INNOVATION CULTURE AS A CHARACTERISTIC OF PERSONALITY AND FORM OF MODERN CULTURE, ITS ESSENTIAL FEATURES
}

\section{Kateryna Kyrylenko}

\section{INTRODUCTION}

The term "innovation culture" has recently been used in the scientific literature as well as in the everyday language. Mostly innovation culture is interpreted by scholars of different fields of knowledge as a personal characteristic of a human, which is connected with their professional development (Ye. Afanasieva, N. Ilina, O. Koiuda, V. Kremen, Ye. Lisin, R. Milenkova, T. Sobol, B. Santo and others). The modern motivational literature (T. Wagner, P. Diamandis, S. Kotler, K. Christensen, S. Covey and others) pays considerable attention to the formation of innovation culture. However, in the works of researchers there is a tendency to highlight innovation culture as one of the defining characteristics of modern culture (K. Robinson, R. Florida and others).

The term "innovation culture" is derived from the term "innovation". It should be noted that the term "innovation" is not identical to the term "novation". Innovations are products of modernity and they emerge in industrial society. Novations take place in any historical period, they have an impact on the development of each culture at a certain stage of its development. Novation can be the subject of innovation. However, it is not necessary even in the modern world. According to E. Rogers, one of the most authoritative modern researchers of the spread of innovations, innovation is not just some idea, solution or object that contains a certain novelty. This is a novelty that receives recognition and usage, and is being shared and implemented. At the beginning of his book "Diffusion of Innovations", the researcher pays attention to conspicuous fact: A. Dvorak keyboard layout, the use of which hasten the transcription on a computer, has not become an innovation, despite its undoubted benefit.

Innovation needs innovators, those who implement and consume it, it needs people with a high level of innovation culture.

The concept of "innovation culture" is now actively used in the sociopolitical context, it is developed in the scientific literature.

${ }^{1}$ Rodzhers Everett, M. (2009). Dyfuzija innovacij. Kyiv: Kyjevo-Moghyljansjka Akademija, pp. 28-30. 


\section{Approaches to defining the term "innovation culture"}

The term "innovation culture" is used in a number of European documents. In particular, in the document entitled "Green Paper on Innovation", which was developed by the European Commission in December 1995. In the document, innovation is regarded as synonymous with successful production, assimilation and use of innovations in economic and social fields. It offers new solutions to problems, and makes it possible to meet the needs of individual and society as a whole. There are many examples of this: the development of vaccines and medicaments, the improvement of transport safety (the emergence of ABS systems, airbags), the emergence of convenient means of communication (cell phones, video conferencing), increased access to know-how (CD-ROM, multimedia), the emergence of new methods of marketing (home banking), improved working conditions, the development of environmentally friendly technology, more efficient public services etc. According to the document, the antonym for the term "innovation" is "archaism and routine". That is why innovation faces a lot of obstacles and such stiff resistance. That is why, "the development and sharing an innovation culture", the document notes, "is becoming a decisive challenge for European societies"

Another document entitled "The First Action Plan for Innovation in Europe" identifies three priority areas for action for the European community: 1) to foster a genuine innovation culture (this area is highlighted as the top priority); 2) to set up a legal, regulatory and financial framework conducive to innovation; 3 ) to gear research more closely to innovation at both national and community level. The document uses the term "genuine innovation culture", it requires such an attitude of the individual to the world, such outlook and life guidelines, which would combine "creativity, entrepreneurship, willingness to take calculated risks and acceptance social, geographical or professional mobility. Being innovative also demands an ability to anticipate needs, rigorous organization and a capacity for meeting deadlines and controlling costs" ". The document refers to the need to encourage the innovative mentality of modern person. Means to act to implement this guideline are: "education and training; easier mobility for researchers and engineers to firms; demonstrate effective approaches to innovation in the economy and in society; propagate the best management and organizational methods amongst businesses; stimulate innovation in the public sector and in government" ${ }^{\prime 4}$.

${ }^{2}$ Green Paper on Innovation. European Union. URL: http://europa.eu/documents/comm/ green_papers/pdf/com95_688_en.pdf.

${ }^{3}$ The First Action Plan for Innovation in Europe - Innovation for growth and employment. Publications Office of the European Union. URL: https://op.europa.eu/en/publication-detail/-/ publication/c1944d2d-b791-4e11-bc42-75c5b6f8ff35/language-en.

${ }^{4}$ Ibid. 
In the study of the European Commission's project "TRANSFORM" (this project deals with the impact of information and communication technologies on the economy and society) called "Transformation of Regional Societies Through ICTs: State(s) of the Art(s)" (2006), the concept of "regional innovation culture" is introduced and it is stated that "regional innovation cultures sit within larger cultural entities (and interact with more territorially dispersed organizational forms, each with its own culture)" Another "TRANSFORM" study called "Differences in Innovation Culture Across Europe" (2008) examines the theories that explain the differences in regional innovation cultures and the impact of regional innovation cultures for economic and social progress ${ }^{6}$. "Innovation culture" in the study is understood in terms of attitude to innovations, technology, knowledge sharing, entrepreneurship, business.

In the scientific literature the term "innovation culture" is interpreted as a culture of attitude to innovations, a culture of their consumption and production. Later, the term "innovation culture" gets a broader interpretation. Innovation culture means the characteristic of a person as a professional in a certain field, which determines their willingness to develop and improve. Innovation culture begins to be understood as a characteristic of a person, which determines their willingness to perceive and produce new things both at the level of everyday life and at the level of professional activity. Innovation culture is a property not only of individuals, but also of groups of people, organizations they work for, and of the entire society.

American economist, professor at the University of Toronto Richard Florida, relying on other researchers (including Joel Mokyr) ${ }^{7}$, writes about the emergence of a new class of people called "Homo creativus". "The mutual commitment to the spirit of creativity in all its variety is precisely what underpins the new creative ethos that is driving our era" "We can and must move from senseless growth (the Industrial Age) to smart growth (the Creative Era), based on use of all human capabilities, that would make us happier, make more impressions, and fill our lives with meaning, not just more material products",

\footnotetext{
${ }^{5}$ Transformation of Regional Societies Through ICTs: State(s) of the Art(s). TRANSFORM. URL: http://www.transform-eu.org/publications/ documents/d1.1_website.pdf.

6 Differences in Innovation Culture Across Europe. TRANSFORM. URL: http:// transform-eu.org/publications/documents/Differences\%20in\%20Innovation\%20Culture.pdf. p. 74.

${ }^{7}$ Floryda, R. (2018). Homo creativus. Jak novyj klas zavojovuje svit. Kyiv: Nash format,

${ }^{8}$ Ibid., p. 29.

${ }^{9}$ Ibid., p. 362.
} 
We believe that innovation culture can be defined as follows: it is a characteristic and component of a general cultural process that determines the degree of perception by an individual, group or society of different novelty in the range of its transformation into innovations.

Numerous definitions of innovation culture, which take place in the scientific literature, can be grouped and the following approaches to their understanding can be distinguished: 1) innovation culture as a degree of implementation of novelty by different historical types of culture (though such an interpretation does not convey the essence of innovation culture; it is more correct to use the phrase "the culture of novelty"); 2) innovation culture as a personal (as well as professional) characteristic of a modern human in the context of their willingness to introduce and produce something new both in a certain field of professional activity and in everyday life; 3) innovation culture as a methodological basis for the improvement and modernization of all spheres of human activity; and, finally, the most extensive and the newest interpretation: 4) innovation culture as a form of modern culture, a new historical reality that has emerged as a result of the transformation of industrial society towards a post-industrial, informational and innovative one, as a result of the particular role of innovations in it.

These approaches clearly distinguish two vectors for understanding the concept: innovation culture as an integral characteristic of the person (or other subject: organization, corporation, institution etc.) and innovation culture as a characteristic and form of modern culture ${ }^{10}$.

Innovation culture as a characteristic of the modern person determines their ability to live in the conditions of constant changes and permanent renewal, readiness for the acquisition of innovations (from tolerant attitude to use and implementation), openness to permanent learning, ability to produce new things. People with a high level of innovation culture are creative, capable of lifelong learning; they are ready not only for perception, assimilation, use of innovations, but also for their creation. An innovation culture of personality can and must be developed in the modern world.

The level of development of an innovation culture of personality is determined by the nature of its attitude to innovations. Everett Rogers is an American sociologist, author of "Diffusion of Innovations" (1962), which has had several reissues and several revised editions during five decades (1971, 1983, 1995, 2006), described psychological portraits of consumers of innovations, based on the level of development of their innovation culture from the highest to the lowest rate of its adoption. Rogers notes that $2.5 \%$ of

${ }^{10}$ Kyrylenko, K., Kunderevych, O., Bojko, L. (2018). Filosofija kuljtury: slovnyk. Kyiv: TOV “Aghentstvo Ukrajina”, p. 71. 
people have a high level of innovation culture, and they are the first who implement innovation (they are "innovators" or trendsetters). $13.5 \%$ of people researcher calls "early adopters". They are people who are ready for something new that has already been partially tested, but has not become rolled-out yet (these people have authority in society, others pay heed to them). The so-called "early majority" and "late majority" have $34 \%$ each they are those who try to keep up with others in their pursuit of the "spirit of the times". About $16 \%$ of people are "laggards", late adepts, they are more conservatives than innovators, but they use the innovation that is widely acknowledged and evident ${ }^{11}$.

An innovative culture of personality is defined as "innovativeness" (the term "creativity" is also used synonymously). Innovativeness characterizes people in their pursuit to creative self-realization in the process of both professional activity and vital self-determination. Innovativeness is a trait of a person, which implies a creative, non-standard, innovative approach to different life situations in different spheres of life, the ability to overcome the commonplaceness, stereotypeness, amorphousness and inertia in creating of something new or developing an existing one. Innovativeness is a consequence of the developed innovation intelligence, the formed innovative thinking, the willingness to innovation activity.

In recent years, the concept of innovation culture has increasingly been used as a characteristic of modern society and its type of culture (T. Wagner, P. Diamandis, J. Mokyr, K. Robinson, R. Florida, etc.). A significant influence on the formation of such an interpretation of innovation culture was made by studies in pedagogy, where the authors raised the question of the relevance of modern education to the needs of modern society and stated the need for the formation of new educational standards. "Nineteenth-century educational ideologies do not succeed in overcoming the challenges of the twenty-first century. We need a new Renaissance that will value different types of intelligence and nurture creative relationships between disciplines as well as between education, business and the general public" - Ken Robinson notes ${ }^{12}$.

The understanding of innovation culture as a form of modern culture is reasonable, because the concept of "the form of culture" refers to a particular cultural product, the technologies by which it is created, and the ideological and methodological principles on which it is based; their core is the outlook inherent in this culture ${ }^{13}$.

${ }^{11}$ Rodzhers Everett, M. (2009). Dyfuzija innovacij. Kyiv: Kyjevo-Moghyljansjka Akademija, p. 313.

${ }^{12}$ Robinson, K. (2017). Osvita proty talantu. Syla tvorchosti. Lviv: Litopys, p. 230.

${ }^{13}$ Levit, S.Ya. (ed.) (1998). Kul'turologiya. XX vek. Entsiklopediya: v 2 t. Saint Petersburg: Universitetskaya kniga; OOO "Aleteyya". URL: http://yanko.lib.ru/books/cultur/culturology 20century2volumes1998sl.htm\#_Toc299572017/. 
Innovation culture as a form of modern culture creates its cultural product, produces technologies by which its artifacts are created, shapes ideological and methodological values, its vision of the world and human. It simulates such a picture of the world, which is the course of a large number of nonlinear processes (it can be recognized by the means of synergetics). Innovation culture as a form of modern culture forms a new (innovative) type of person, appropriate (innovative) content of modernity. It correlates with such modern concepts as post-industrial society and information culture. Innovation culture is antithetical to mass culture in post-industrial society. The emergence of the Internet and the processes of digitalization that are currently active are the result of the creation of an innovation culture.

Scientific discourse evolves from understanding the term "innovation culture" as a characteristic of the individual to its interpretation as a form of modern culture.

An innovation culture, interpreted either as a characteristic of the individual or as a form of modern culture, has end-to-end characteristics. The essential features of innovation culture are dialectical unity: traditions and innovations (vertical or diachronic section), humanitarian and natural science knowledge (and forms of culture) - (horizontal or synchronous section), which is embodied in creative form in the process of creative realization of new ideas. These ideas arise as a result of the people's perception of the world as an open nonlinear system capable of producing something new (such a picture of the world is described by synergetics - the science of the development of nonlinear systems). Therefore, innovation culture has a fundamental integrity as its cornerstone. It is focused on creating of something new by taking into account the progressive modernity, while preserving the achievements of the past. Innovation culture is aimed at combining natural science and humanitarian knowledge, at combining rational and intuitive in the direction of forming a new integral innovative (evolutionary-synergetic) picture of the world.

\section{Diachronic section of innovation culture: unity of tradition and innovation as a characteristic of innovation culture}

The unity of tradition and innovation, past, present and future in the content of innovation was pointed out by American scientist Peter Drucker ${ }^{14}$. Innovation offers such a "new", which is not a denial of the existing one, but its improvement; in addition, it needs to be copied and used, which is possible only if it is tested, assimilated, processed when it becomes such a new that is

${ }^{14}$ Drucker, P. (2001). Management Challenges for the 21st Century. New York: Harper Business. 
already habitual or traditional. Innovation does not remain an innovation for a long time, it tends to be a modern tradition, and eventually it naturally becomes. The term "tradition" comes from Latin "tradition" and means "transmission". Innovation is the "introduction" of the new both into the wide environment of replication-use, and in the tradition itself (any tradition emerges initially as innovation). Therefore, innovations arise in the depths of tradition and involves communication with it.

The tradition that emerges as a way of being and reproducing the cultural heritage, as a cross-cutting line of the cultural evolution of mankind, and the innovation that arises as the intention to offer something fundamentally different, are presented in every historical epoch, in each certain phenomenon of culture, in every individual. Various cultural and philosophical paradigms, as well as certain periods of development of human history within these paradigms, have had primacy over tradition and innovation. In particular, the Oriental paradigm of philosophizing has always preferred tradition over innovation, has cultivated the preservation, study, and reproduction of tradition. However, the current socio-political success of the countries that are its prime representatives - for example, China - demonstrates that this commitment to tradition has a strong potential to find the new, interesting innovative ideas and solutions. The Western paradigm of philosophizing prefers innovation, and each new period of time must go beyond the achievements of the previous one. However, a closer examination of evolutionary processes within the emergence of Western type of philosophizing shows the close and deep-rooted interconnections of different epochs. The most striking example of distinguishing one epoch from the achievements of another one that led to temporary interruption of historical progress is the critical attitude of the Renaissance humanists to the medieval inheritance, which Hegel later proclaimed as "the abyss of human history", "the Dark ages" in the history of mankind ${ }^{15}$. However, it is precisely from the philosophical heritage of the Middle Ages the distinction between religious and secular knowledge (the theory of Averroism or the double truth of Ibn Rushd), espoused by humanists, originates; proclaiming God as an "absolute maximum" (Nicholas of Cusa) was not intended to diminish his significance, but to determine the greatness and unknowability of his essence, etc. The eloquent image of the dialogue of the other two epochs - the Middle Ages and Antiquity - is suggested by J. Le Goff in his famous work "Medieval Civilization"16 : thinkers of the Middle Ages seem to continue to weave the fabric, which the thinkers of

\footnotetext{
${ }^{15}$ Gegel', G.V.F. (1993-1994). Lektsii po istorii filosofii. Saint Petersburg: Nauka.

${ }^{16}$ Le Goff, Zh. (1992). Tsivilizatsiya srednevekovogo Zapada. URL: https://www.gumer.info/ bibliotek_Buks/ History/Goff/index.php.
} 
Antiquity put into the loom; indeed, without the philosophical heritage of Plato and Aristotle, and the ongoing debate between their ideas, it is impossible to understand the search of the essence of universals made by the scholastics, and the controversy about universals has become the core of the entire period of scholastic philosophizing of the Middle Ages.

In tradition you can follow some of the defining characteristics of it. First of all, repetitiveness, as long as tradition must be reproduced, fixed, and have as many reproductions as possible. In addition, tradition is always selective, it refers not to the logical-theoretical mind, but to the so-called "motivational component of the consciousness of the individual"17, because tradition is not the realization of structural components (such as human thought), but the choice and assimilation after conscious study and the processing of some material borrowed from the outside (if it is an individual tradition, then the individual's prior experience will be such an external context). Tradition is also characterized by polysemy, it can be assimilated and interpreted differently. In the tradition, there is some "authoritarianism" in the context of the presence and dominance of authorities (external or internal), whose opinion is always a determining factor for assimilating the tradition (it is needed to distinguish between a tradition that is of a spontaneous nature, its certain characteristics are presented implicitly and it can hardly be considered a tradition in the full philosophical meaning, and a tradition that is a conscious elaboration and assimilation of previous cultural content and forms). Tradition always accumulates a certain "code" of the previous culture (its system of norms, customs, outlook principles and values, etc.), this coding system can occur either by the Euclidean geometry model, when only the main is assimilated, or by the model of the oriental type of culture broadcasting, when attention is paid to the special and atypical, but such coding always takes place. Tradition emerges as the mediator, the conductor of cultural content and the cultural core of humanity, it is a communicator between generations, the archiver of experience, the framework for action is passed to future generations from their predecessors through tradition as a question that has not been answered yet. Tradition, in the simplest way, reproduces itself through customs, ceremonies, rituals, which are easily learned and regularly reinforced through repeated actions and duplications.

Innovation is the creation of something new, search for something that did not exist before. The problem of the creation of the new has repeatedly been the subject of study of both philosophy and psychology of art. For instance, the representatives of German classical philosophy (Kant, Hegel) the emergence of the new and unique in art associated with the realization of

\footnotetext{
${ }^{17}$ Apresyan, R.G., Guseynova, A.A. (2001). Etika. Entsiklopedicheskiy slovar’. Moscow.
} 
talent and display of genius. In the XX century a new integrative study of creative thinking, the methodology of acquiring the new in different fields of cognition - eristic - was formed. Depending on the line of research, scientific, legal, engineering, pedagogical and other eristic are highlighted.

The importance of innovative forms and contents is an essential feature of the western type of culture, whose homeland was the ancient culture. The guiding principle of this tradition to new forms and content, as well as to their struggle with the outdated, is rooted in the image of Prometheus, who defies the gods, and then goes through all epochs to make himself known. Ancient and medieval culture is dominated by tradition, despite the emergence of new cultural forms and content, and the emergence of Christianity is a vivid example. However, everything new that arises in these historical and cultural types originates for the purpose of archiving the existing or creating something that will be its preservation and reproduction. Since the Renaissance, innovation has been gaining ground. The need for the new, the change of the existing, the expansion of rational logical and theoretical discourse are becoming the dominant values of humanity. The classical tradition of philosophizing, which had its direct transcription in culture and art, sought to balance the dualism of tradition and innovation, focusing on one pole in this pair of concepts, then on the other (for example, for romanticism, as an artistic style, priority was given to innovation which had its energetic potential. For classicism tradition played a dominant role; everything beyond its boundaries must have been overcome. In the conflict of feeling and obligation, the judgment of the latter prevailed). The postclassical artistic paradigm formed the attitude to the tradition which was the most radical in Western culture. It was proclaimed a brake of development, an obstacle to the universal renewal of art. Innovation, as the antithesis of a tradition that does not allow the new to come true, has its fullest manifestation in postulates and stylistic means of avant-garde art. However, the tradition was implicitly represented there as well. Non-classical philosophy and art continued to develop the inheritance of classical culture, they took into account all the taboos of their predecessors, everything that was outside the sphere of rational before.

Efforts to change the world for the better, to find more sophisticated forms, new recipes for solving new problems aim to realize the new; a challenge to people, the world and God are in the nature of innovation. The path of humanity through the mazes of its history is the path of innovation progress. The new is slowly reclaiming more and more planes for its own realization, starting from value-neutral contexts, from improvements of means of labor and logistical innovations, at the same time reaching awareness of the possibility and necessity of changes in the social, political, moral, ideological 
environment. The nature of innovation in industrial society was pointed out, in particular, by D. Bell, according to whom the classical culture of the era of industrial society has a dualistic character, it is innovative in the production sphere and traditional in the non-productive sphere. A post-industrial society, whose structures are developing strongly nowadays, overcomes this dualism, blurs the borders proclaimed by it $^{18}$.

\section{A synchronous section of innovation culture: the unity of natural science and humanitarian knowledge} as a characteristic of innovation culture

Innovations penetrate all spheres of society and human life. In the second half of the XX century innovations in their transformed form have become not only the dominant trend of time, they have also become a special profession (so-called venture firms, specializing in the discovery of new technologies and new markets, emerged; stakeholders, people who influence activities or decisions, are becoming more popular).

The technical capabilities gained by modern mankind increasingly call into question the self-sufficiency of any innovations. Change for the sake of change, for the sake of the new becomes more and more problematic, demonstrating the obvious absurdity of this guideline.

The global problems of humanity have clearly demonstrated the imperfection of only a technically and technologically oriented civilization. The self-sufficiency of the new is increasingly questioned. The unchanged is increasingly cultivated (from natural foods to natural artifacts as perfect art forms); the cult of archaicism, the mythologization of modern culture, the creation of its own mythology (which does not change and is replicated), are vivid examples.

We can make a statement that the striving for self-sufficiency of the new is long gone. Nowadays researchers warn against a cult of novelty existing in society, which leads to pseudo-innovations or innovative pathology, when the new is not better but sometimes worse than something that already exist; and it can be seen as evidence of the dominant role that innovations play today. Paradoxically, in modern technical and technological world, innovations are "dying" to be reborn in a more sophisticated form. Let's recall that the term "innovation" is derived from Latin "innovatio" - "update", "recovery", "change", it is also etymologically associated with the English word "innovation" - novelty. Innovation is the denial of the new: everything that is created is not radically different, distinct from the tradition. Innovation is a modern response to the harmony of tradition and novelty, intuitively sought

${ }^{18}$ Bell, D. (1996). Prykhid postindustrialjnogho suspiljstva. Kyiv: Lybidj. 
by the classical paradigm of culture, which is so nostalgic for modernity. In our opinion, the era of innovations removes the antagonism that has taken place in the thinking of previous eras and offers a new model of coexistence of tradition and novelty through innovation.

In the modernity we can ascertain the origin of that harmonious combination of science and poetry (Schelling), Apollonian and Dionysian (Nietzsche), rational and non-rational, that was the subject of works of different philosophers during the history. The impetus to find the mechanisms for such a combination is an urgent need to overcome an ideological crisis that has engulfed all of humanity and is constantly reminding itself because of the need and impossibility to solve the global problems.

An innovation culture is a culture aimed at finding, creating and introducing the new, while preserving the existing for the sake of the future. It seeks to find such the "new" that will clearly benefit from its use and implementation, to this end it integrates the old and the new, tradition and innovation, and seeks new ways of atypical combinations. The ideological and theoretical basis of the innovation culture, outlined in the synergetic postulates, convinces of the possibility and the productivity of such an approach.

Innovation combines not only tradition and novelty, but also technical and aesthetic, scientific and artistic principles, it emerges as a dialectical unity of natural science and humanitarian knowledge.

The juxtaposition of humanitarian and natural knowledge, despite some differences in the subject of study (the sphere of the spiritual life of human and the world is the object of knowledge of the humanitarian, and the sphere of the natural is studied by the naturalist), is, rather, evidence of differences in their search for methods of constructing their theoretical basis, the main purpose - the establishment of truth and the construction of a coherent theoretical framework - is common.

Modern science, traditionally differentiated into the natural sciences and humanities, is the heir to a worldview paradigm that traces its origins back to the Antiquity, its key tenets about the need to study the world through mind were formed in the Renaissance and received their theorizing in the modern history. This differentiation (natural and humanitarian knowledge) was formed as a result of elaboration of theoretical postulates of the modern history, which continued the idea of the Renaissance humanists about the necessity of studying the world, and secularization of scientific knowledge was continued and theoretically proved. Before the philosophy of the modern history, the differences of "natural sciences" and "spiritual sciences" were mentioned only in order to substantiate the integrity formed by the relationship between them (cosmogonic integrity of the universe was proved 
by ancient thinkers, medieval mystics sought for ways of material realization of spiritual truths, romantics dreamed about the integrity of the world and the knowledge that humanity had collected created by science and art).

The juxtaposition of the "natural sciences" and the "spiritual sciences" was initiated by a non-classical philosophical tradition, which made it the subject of its study. This juxtaposition (the "natural sciences" and the "spirit sciences") was carried out in the works of representatives of the Baden School of Neo-Kantianism by W. Windelband and H. Rickert. The purpose was to substantiate the epistemological originality and status of social and humanitarian disciplines which differ from natural science. In the scientific discourse of the XX century the juxtaposition was subsequently changed to a distinction, often antagonistic. Such a distinction casts doubt on both modern science and the practice of the everyday life of a person of the XXI century.

In the middle of $\mathrm{XX}$ century the issue of comparing the humanities and natural sciences has received a new vector of discussion because of the publication of the book by American researcher C. P. Snow "The Two Cultures", which has spread the ideas he presented on May 7, 1959 at a lecture at Cambridge University. The researcher notes the distinction of social-humanitarian and natural knowledge and their spheres of activity in the modern world, warns against the dangers of such distinction, and points to the integration between them as the only productive path of development. "The clashing point of two subjects, two disciplines, two cultures - of two galaxies, so far as that goes - ought to produce creative chances. In the history of mental activity that has been where some of the break-throughs came. The chances are there now"19.

Opinions about the harmfulness of the distinction of natural science and humanitarian knowledge were also expressed by the French philosopher O. Koyré. Although science deals with quantity as a category that captures the diversity of the world, and culture (as the embodiment of humanitarian knowledge) with quality, science and culture are closely intertwined. Scientific thought has always arisen in an environment of intellectuals of different times, who were concerned not only with theoretical searches in a particular field, but also with the ideological problems that were the subject of the widest debate, and the great scientific revolutions in the history of mankind have always resulted in a change in philosophical concepts ${ }^{20}$.

The philosopher's ideas about the impact of humanitarian studies on the development of the natural sciences are confirmed by many examples.

\footnotetext{
${ }^{19}$ Snow, C.P. (1998). The Two Cultures. New York: Cambridge University Press, p. 16

${ }^{20}$ Koyre, A. (1985). Ocherki istorii filosofskoy mysli. Moscow: Progress.
} 
In particular, the physical ideas of W. Heisenberg were influenced by the philosophy of Plato, N. Bohr's concept of complementarity was the result of reflections on the philosophical ideas of S. Kierkegaard, E. Schrödinger's quantum mechanics was formed under the influence of ancient Indian philosophy, A. Einstein pointed out that F. Dostoevsky gave him more than physicist Gauss. Moreover, a number of scientific ideas were firstly formulated in philosophical works. For instance, the ancient Greek philosopher Thales of Miletus wrote about water as the primary and the first element of the world, which contains "everything" in itself; another thinker of the time, Democritus, was first who proposed the concept of an atom and developed it, noting the relationship between atom mass and velocity, later justified by I. Newton. Or another example. The speed of light became known in the West only in the XVII century. However, it is referred to in one of the Vedas, the religious and philosophical text of ancient India. As noted by Manoj Kumar Bharti in his book "Understanding Indian Philosophy Through Modern Science", the Asanaveda text indicates the speed of light calculated in units of measurement that existed in the culture of ancient India. This figure is the same as the speed of light calculated by scientists and recorded in modern units of measurement. The inaccuracies that occur between these figures are very minor ${ }^{21}$.

Both C. P. Snow, O. Koyré, and other scholars have pointed out that scientific ideas are always the result of intellectual communication, whose subject of discussion is primarily a matter of worldview. So cultural and philosophical studios have a strong creative potential for scholars of natural sciences.

However, this influence is interrelated. A vivid example is the story of the painting "Galatea of the Spheres" (1952) by Salvador Dali, one of the main representatives of twentieth-century surrealism, which is stored in the collection of the Dali's Theatre-Museum in Figueres. The picture is the result of Dali's fascination with the theory of radioactive decay, the physics of the atomic nuclei, and of elementary particles, which was the subject of discussions by intellectuals of the time. The theory of radioactive decay is based on the assumption that radioactive decay is a spontaneous process, the speed of which is not affected by any external changes in temperature, pressure, the presence of electric and magnetic fields, etc. Radioactive decay is a property of the atomic nuclei, and it depends only on its internal state. The artist's wife Gala's face is made up of individual fragments, which are spheres of different sizes and colors that create a three-dimensional image

${ }^{21}$ Manoj, K. Bharti (2018). Understanding Indian Philosophy through Modern Science. Brand Books. 
with its own axis of symmetry. Another widely publicized example is the office building in Zimbabwe, Harare, which is designed by Mick Pierce ${ }^{22}$. Born in Zimbabwe, he studied architecture in London and, besides admiring the architecture, had a keen interest in exploring the world of natural ecosystems. M. Pierce laid the principle of construction of the anthill as the basis of his architectural project. The office building was opened in Zimbabwe in 1986. It is interesting that a temperature of $+22 /+24{ }^{\circ} \mathrm{C}$ is maintained in the building without the use of air conditioning. The example cases are not alone.

\section{CONCLUSIONS}

The syncretic and synthetic nature of innovation culture makes it a culture of creativity. Innovation culture requires the development of creativity, associative and integrative thinking not only from individuals but also from the general public.

Creativity is the activity of a person, where the creation of something qualitatively new is the result. Creativity has a non-linear synergistic nature, emergent structure and bifurcation-ambivalent structure. In creativity, the flexibility of the mind and the productivity of the imagination, the divergence (the ability to disperse in different directions) and the alternativeness (the ability to overcome stereotypes and clichés, to search for new options), the ability to empathy and altruism play an important role. Both inspiration and insight, and systematic and persistent work play an important role in the creative process. All stages of the creative process are the syncretic unity of the conscious and the unconscious. Creativity is described as the unity of the three S: Sensivity, Synergy, Serendipity.

Innovation culture is a culture of creative combination of tradition and novelty, humanitarian and natural knowledge, rational and non-rational principles in order to create something new that can help modern humanity not only solve urgent problems of life but also solve urgent problems of survival. The theoretical basis of innovation culture is the modern non-linear picture of the world, which is explained by synergetics as a science of the formation and development of open systems.

The picture of the world is a cognitive basis of the worldview, a set of ideas about the structure of reality, ways of its functioning and changes. An important component of the picture of the world is the scientific picture of the world. By the term "scientific picture of the world" we mean a holistic

\footnotetext{
${ }^{22}$ Jokhanson, F. (2011). Efekt Medychi: innovacijni vidkryttja na peretyni idej, koncepcij ta kuljtur. Lviv: Ukrajinsjkyj Katolycjkyj Universytet, pp. 19-20. 
system of ideas about the world, its general properties and patterns, which arise as a result of generalization and synthesis of concepts, principles of natural sciences, humanities and other sciences; it is a set of substantive content that a person possesses.

The modern, post-nonclassical picture of the world is evolutionarily synergistic and has a paradigm of formation and self-organization. Synergetics, a science that studies the general principles of the processes of self-organization that take place in systems of different nature, formulates the basic ideological and methodological foundations of the post-classical picture of the world. The founder of synergetics is the German physicist H. Hacken ${ }^{23}$. The post-nonclassical picture of the world is focused on integrity and development as the most important characteristics of being. Since the emergence of synergetics as a science, they have been talking about synergistic principles in the natural sciences, but nowadays researchers demonstrate the productivity of applying these ideas to the humanities in order to study better the subject of knowledge of these sciences, which is changing dynamically.

Features of the modern scientific picture of the world are recognition of the irreversibility of evolutionary processes that have a nonlinear character; substantiation of the bifurcation nature of evolution; the perception of the world as a complex system that can change structurally (due to the restructuring of its structure) and systematically (by moving to another level); understanding the world as a whole with a fractal structure and subordinated to the principle of the emergence (when the whole is greater than the sum of its parts); the perception of chaos is as real and constructive as orderliness; understanding the future as a spectrum of alternative scenarios, where each is probable.

The basis of synergetics is the understanding of the world as the non-linear whole.

Synergetics builds an evolutionary synergistic picture of the world, fundamentally different from the classical Kantian and non-classical quantumrelativistic ones. According to it, the world exists as a set of different nonlinear processes capable of occurring spontaneously. The picture of the world is integrated and pluralistic.

Innovation culture emerges as a consequence of embodying the principles of the evolutionary synergistic picture of the world, as a response to the demand for the embodiment of its ideological principles in sociocultural practices. A powerful impetus for the development of an innovation culture is

${ }^{23}$ Haken, H. (2012). Advanced Synergetics: Instability Hierarchies of Self-Organizing Systems and Devices. New York: Springer Science \& Business Media. 
the urgency of solving global problems of humanity. These problems arise as a result of embodying the philosophical principles of the classical and partly non-classical picture of the world. It is not possible to solve these problems on the basis that produces them. The post-classical picture of the world forms such a powerful potential.

An innovation culture is a way to solve global problems of modernity, it is a way for humanity to the joint creation of its own future.

\section{SUMMARY}

The article deals with the term "innovation culture" which now is increasingly used. Two approaches to its interpretation are dominant: as an integral characteristic of the person (or other entity: organization, corporation, institution, etc.) and as characteristics and forms of modern culture. Within both contexts, the essential features of innovation culture are traced: the dialectical unity of tradition and innovation (vertical section) and the unity of humanitarian and natural science knowledge (and forms of culture) (horizontal section). Innovation culture has a fundamental integrity as its cornerstone. It is a culture of creativity, it requires the development of creativity, associative and integrative. The ideological principles of innovation culture are shaped by a modern, non-linear picture of the world. Synergetics provides the methodological basis for understanding the innovation culture.

\section{REFERENCES}

1. Apresyan, R.G., Guseynova, A.A. (2001). Etika. Entsiklopedicheskiy slovar'. Moscow.

2. Bell, D. (1996). Prykhid postindustrialjnogho suspiljstva. Kyiv: Lybidj.

3. Differences in Innovation Culture Across Europe. TRANSFORM. URL: http://transform-eu.org/publications/documents/Differences\%20in\%20 Innovation\%20Culture.pdf.

4. Drucker, P. (2001). Management Challenges for the 21st Century. New York: Harper Business.

5. Floryda, R. (2018). Homo creativus. Jak novyj klas zavojovuje svit. Kyiv: Nash format.

6. Gegel', G.V.F. (1993-1994). Lektsii po istorii filosofii. Saint Petersburg: Nauka.

7. Green Paper on Innovation. European Union. URL: http://europa.eu/ documents/comm/green_papers/pdf/com95_688_en.pdf.

8. Haken, H. (2012). Advanced Synergetics: Instability Hierarchies of Self-Organizing Systems and Devices. New York: Springer Science \& Business Media.

9. Jokhanson, F. (2011). Efekt Medychi: innovacijni vidkryttja na peretyni idej, koncepcij ta kuljtur. Lviv: Ukrajinsjkyj Katolycjkyj Universytet. 
10. Koyre, A. (1985). Ocherki istorii filosofskoy mysli. Moscow: Progress.

11. Kyrylenko, K., Kunderevych, O., Bojko, L. (2018). Filosofija kuljtury: slovnyk. Kyiv: TOV “Aghentstvo Ukrajina”.

12. Le Goff, Zh. (1992). Tsivilizatsiya srednevekovogo Zapada. URL: https://www.gumer.info/bibliotek_Buks/ History/Goff/index.php.

13. Manoj, K. Bharti (2018). Understanding Indian Philosophy through Modern Science. Brand Books.

14. Robinson, K. (2017). Osvita proty talantu. Syla tvorchosti. Lviv: Litopys.

15. Rodzhers Everett, M. (2009). Dyfuzija innovacij. Kyiv: KyjevoMoghyljansjka Akademija.

16. Levit, S.Ya. (ed.) (1998). Kul'turologiya. XX vek. Entsiklopediya: v 2 t. Saint Petersburg: Universitetskaya kniga; OOO "Aleteyya". URL: http://yanko.lib.ru/books/cultur/culturology20century2volumes1998sl.htm\#_T oc299572017/.

17. Snow, C.P. (1998). The Two Cultures. New York: Cambridge University Press.

18. The First Action Plan for Innovation in Europe - Innovation for growth and employment. Publications Office of the European Union. URL: https://op.europa.eu/en/publication-detail/-/publication/c1944d2d-b791-4e11bc42-75c5b6f8ff35/language-en.

19. Transformation of Regional Societies Through ICTs: State(s) of the Art(s). TRANSFORM. URL: http://www.transform-eu.org/publications/ documents/d1.1_website.pdf.

Information about the author: Kateryna Kyrylenko,

Doctor of Pedagogical Sciences, Associate Professor, Head of the Philosophy and Pedagogy Department, Kyiv National University of Culture and Arts, 36, Y. Konovalets str., Kyiv, 01133, Ukraine http://orcid.org/0000-0002-3303-3947 